\title{
MANAJEMEN KINERJA GURU SEKOLAH DASAR
}

\author{
Oleh: \\ Sudrajat \\ Universitas Pendidikan Indonesia \\ (email: csudrajat1969@gmail.com )
}

\begin{abstract}
ABSTRAK
Tujuan dari Penelitian ini adalah menggambarkan manajemen kinerja guru Sekolah Dasar yang secara konseptual dirumuskan ke dalam tiga komponen esensial, yaitu utama (core performance), unsur pendukung (supporting elements), dan faktor kepemimpinan kepala sekolah (school principalship as prime mover) sebagai satu kesatuan di dalam manajemen kinerja guru. Metode penelitian ini menggunakan pendekatan kualitatif dengan instrumen pengumpulan datanya berupa observasi, wawancara, dan studi dokumentasi, sedangkan Sumber datanya adalah guru kelas dan Kepala Sekolah Dasar yang tersebar di kluster 1 dan kluster 2 wilayah Kabupaten Sukabumi. Hasil penelitian menunjukkan bahwa keterlaksanaan manajemen kinerja guru Sekolah Dasar yang mempertimbangkan unsur utama, unsur pendukung, dan fungsi kepemimpinan kepala sekolah diyakini dapat menjamin efektivitas keterlaksanaan proses dan hasil pembelajaran serta terdapat temuan tidak optimalnya hasil kinerja yang meliputi kurikulum sebagai sumber kompetensi, pemaknaan kompetensi oleh guru, tampilan kinerja guru yang kurang baik, kelengkapan perangkat pembelajaran, penugasan guru tidak jelas, faktor eksternal yang menghambat motivasi guru, kondisi kerja tidak kondusif, tidak optimalnya kegiatan supervisi, pengembangan profesi, dan evaluasi kerja, serta terbatasnya sumber pembiayaan. Sedangkan kepala sekolah belum memfungsikan kepemimpinannya sebagai prime mover.
\end{abstract}

Kata Kunci: Kepemimpinan Kepala Sekolah, Manajemen Kinerja Guru, Unsur Pendukung Kinerja, Unsur Utama Kinerja

\begin{abstract}
The focus of the research is the management of elementary school teacher's performance that a framework conceptually formulated consists of core performance, supporting elements, and school principalship as a prime mover as a single entity in the management of elementary school teacher's performance. The research applied a qualitative method and using three data collection: guided interviews observation, and a review of relevant documentation. Sources of data is the elementary school teachers and principals at the area of cluster of 1 and 2 in the District of Sukabumi. Findings of the research are as follows The implementatation of the management of elementary school teacher's performance who consider the core performance; supporting elements, and the function of school leadership is believed to be able to guarantee the implementation of process and learning outcomes; and There is no optimal outcome's performance on the core performance of which include: curriculum as a source of competence, meaning competence by teachers, the teacher's performance is not good, and completeness of the learning device. In the supporting elements include the assignment of teachers is unclear, external factors that hinder motivation of teachers, working conditions are not conducive, not optimal of supervision activities, professional development, and appraisal performance, and the limited sources of financing. While principals have not functioning leadership as the prime mover.
\end{abstract}

Keywords: Core Performance, Supporting Elements, School Principalship As Prime Mover, The Management of Elementary School Teacher's Performance.

\section{PENDAHULUAN}

Dewasa ini, profesi guru menjadi fenomena menarik, banyak dibicarakan dan dipertanyakan orang. Bukan karena peningkatan kesejahteraannya saja yang mulai dilirik, tapi hal lain terkait kompetensi, persebaran, jati diri, dan eksistensi. Ini menandakan betapa kehadiran guru sebagai profesi menjadi penting adanya.

Berangkat dari konseptual framework manajemen guru dalam konteks life cycle guru menurut Fessler (dalam White, Ron. 2008), yaitu yang dimulai darifase calon guru, kemudian fase kemapanan menjadi guru, dan diakhiri dengan fase mengakhiri profesi guru (Career Exit). Penulis mendapati rincian aktivitas setiap fase tersebut dalam tiga belas aspek besar, yaitu: (1) Pendidikan Calon Guru; (2) Rekrutmen Calon Guru; (3) Pengangkatan (appointment); (4) Penempatan (placement); (5) Induksi Guru; (6) Penugasan dan Pemanfaatan (Utilization); (7) Kinerja Guru (Performance); (8) Supervisi; (9) Pengembangan Profesi Berkelanjutan (Continuing Professional Development); (10) Evaluasi 
(Performance Evaluation); (11) Kesejahteraan Guru (Welfare); (12) Pensiun Guru (Retirement); dan (13) Post Retirement Program.

Berdasarkan konsep tersebut, maka ada satu elemen khusus sebagai isu strategis yang membutuhkan kajian khusus terkait manajemennya, yaitu manajemen kinerja guru. Manajemen kinerja guru yang menjadi fokus kajian penelitian ini membutuhkan elemen-elemen kinerja guru yang merupakan bagian tidak terpisahkan, bahkan mungkin bisa beririsan langsung dengan konseptual framework life cycle guru.

Pengkajian tentang manajemen kinerja tersebut perlu difokuskan pada level kajian operasional (praktis). Mengingat pada level persekolahan merupakan level yang paling operasional dimana manajemen kinerja guru diterapkan, maka penulis melakukan kajian ini bertahap mulai dari manajemen guru mulai dari level mikro atau level persekolahan, berlanjut ke tingkat kluster, tingkat kecamatan, hingga menjadi rekomendasi bagi tingkat kabupaten. Guru dan

Manajemen sekolah dapat diartikan sebagai segala sesuatu yang berkenaan dengan pengelolaan sekolah untuk mencapai tujuan yang ditetapkan, baik tujuan jangka pendek, menengah, maupun tujuan jangka panjang. Gaffar, Fakry (1989) mengemukakan bahwa manajemen sekolah mengandung arti sebagai suatu proses kerjasama yang sistematik, sistemik, dan komprehensif dalam rangka mencapai tujuan pendidikan nasional. Proses pendayaguaan semua komponen sekolah dasar disebut dengan kegiatan manajemen Sekolah Dasar. Para pakar administrasi pendidikan telah mencoba mengklasifikasi komponen-komponen tersebut menjadi beberapa gugusan substansi pendidikan, yaitu gugusangugusan substansi (1) kurikulum atau pembelajaran; (2) kesiswaan; (3) kepegawaian (guru dan tenaga kependidikan); (4) sarana dan prasarana; (5) keuangan; dan (6) lingkungan masyarakat.

\section{Manajemen Guru}

Untuk mewujudkan guru yang berkualitas diperlukan manajemen guru yang efektif mulai dari pengangkatan, penempatan, kepala sekolah menjadi informan kunci, sedangkan sekolah dijadikan sebagai obyek lembaga/ organisasi kajian pada penelitian ini.

Fokus dalam penelitian ini adalah manajemen kinerja guru SD yang secara konseptual dirumuskan ke dalam tiga komponen esensial, yaitu utama (core performance), unsur pendukung (supporting elements), dan faktor kepemimpinan kepala sekolah (school principalship as prime mover) sebagai satu kesatuan di dalam manajemen kinerja guru. Unsur utama tersebut meliputi: kurikulum; pemaknaan kompetensi oleh guru; tampilan kinerja guru; dan perangkat pembelajaran. Unsur pendukung meliputi: penugasan guru; motivasi guru; kondisi kerja; supervisi; pengembangan profesi guru; evaluasi kinerja; dan pembiayaan. Sedangkan fungsi kepemimpinan Kepala Sekolah berperan sebagai perencana, pengorganisasi, pengkoordinasi, sinkronisasi, pengendalian, dan pengevaluasi efektivitas kebijakan.

\section{Manajemen Sekolah Dasar}

induksi, kesejahteraan, dan pengembangan profesi guru. Guru yang berkualitas dipengaruhi oleh banyak faktor diantaranya adalah kualitas calon guru yang masuk di embaga Pendidikan Tenaga Kependidikan (LPTK) dan proses pendidikan di LPTK.

Salah satu bab dalam laporan penelitian PISA atau TIMSS tertulis secara bombastis "the quality of an education system cannot exceed the quality of the teacher". (Barber and Mourshed, 2007). Guru yang dalam pendidikan dan rekrutmen dilakukan dengan kualitas baik, tidak akan dapat menghasilkan kualitas pendidikan yang tinggi apabila pola penempatan dan pembinaanya tidak dilaksanakan secara adil dan proporsional yang diikuti dengan proses pembinaan yang terus menerus. (Tilaar, 2002). Para ahli berpendapat bahwa rekrutmen guru yang efektif dilanjutkan dengan penempatan guru yang sistematis, adil, proporsional, dan imbalan yang baik perlu ditunjang dengan sistem pembinaan keprofesionalan yang terus menerus.

\section{Manajemen Guru dalam Konteks Life Cycle Guru}

Dalam kerangka yang lebih luas, manajemen guru sesungguhnya tidak lepas dari konsep Life cycle. Sementara itu, Life cycle bukanlah konsep yang berdiri sendiri sebagai konsep manajemen guru. Sebab, dalam biologi pun konsep ini senantiasa menjadi bahasan utama 
siklus kehidupan. Beberapa peneliti mengadopsi konsep ini terkait dengan manajemen guru. Mungkin saja hal ini dipakai karena ada kesamaan fase dalam siklusnya, sehingga Fessler (dalam White, Ron. 2008) merekomendasi hasil penelitiannya tentang teachers' professional growth and development, yaitu Pre-Service; Induction; Competency building; Enthusiastic \& Growing; Career Frustration; Stable \& Stagnant; Career Wind-down; dan Career Exit. Yang paling fenomenal terkait manajemen guru ini, sebagaimana hasil penelitian Huberman bahwa guru dalam siklus karirnya menempuh tiga fase utama, yakni Novice, Mid-career, dan Latecareer.

Dengan demikian, manajemen guru merupakan aktivitas menjalankan fungsi manajemen dalam lingkup siklus kehidupan guru yang meliputi: Pendidikan Calon Guru, Rekrutmen Calon Guru, Pengangkatan, Penempatan, Induksi Guru, Penugasan dan Pemanfaatan, Kinerja Guru (Performance), Supervisi, Pengembangan Keprofesian Berkelanjutan, Evaluasi, Kesejahteraan Guru, Pensiun Guru, dan Post Retirement Program.

\section{Manajemen Kinerja}

Cummings, T.G Worley, C. G. (2001) mendefinisikan manajemen Kinerja (performance

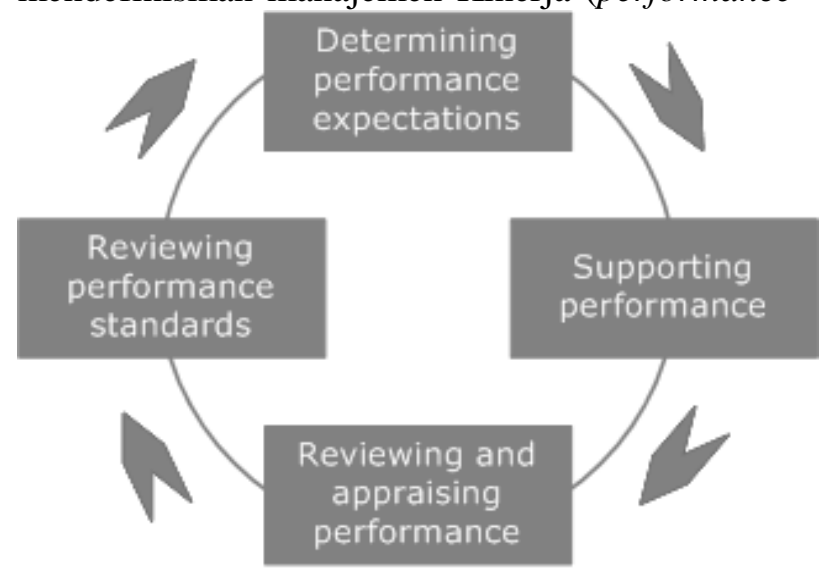

Gambar 1 Manajemen Kinerja Model Torrington dan
Hall
Manajemen Kinerja Guru

Beberapa persoalan mengemuka terkait penataan dan pengelolaan guru. Agar kinerja guru dapat selalu ditingkatkan dan mencapai standar tertentu, maka dibutuhkan suatu manajemen kinerja (performance management). Mengacu pada pemikiran Bacal, Robert (2001) bahwa manajemen kinerja dipandang sebagai:

“... sebuah proses komunikasi yang berkesinambungan dalam kemitraan antara seorang karyawan dan penyelia langsungnya. management) sebagai sebuah proses terpadu dalam mendefinisikan, menilai dan memperkuat tingkah laku kerja pegawai dan hasil nya. Proses ini meliputi praktek-praktek dan metode-metode dalam menyiapkan tujuan, penilaian kinerja (performance appraisal), dan sistem penghargaan.

Model manajemen kinerja Torrington dan Hall menjadi rujukan penulis dalam membahas dan menganalisis temuan penelitian. Alasan model ini sebagai rujukan terletak pada rasionalitas setiap tahapan (aspek) yang dikemukakan Torrington dan Hall dengan kesesuaian karateristik kinerja guru sebagai subyek penelitian ini. Torrington dan Hall (Torrington, D., Hall, L., Taylor, S. 2008) menggambarkan proses manajemen kinerja dengan merumuskan terlebih dahulu harapan terhadap kinerja atau hasil yang diharapkan dari suatu kinerja. Kemudian, ditentukan dukungan yang diberikan terhadap kinerja untuk mencapai tujuan. Saat pelaksanaan kinerja berlangsung dilakukan review dan penilaian kinerja. Langkah selanjutnya melakukan pengelolaan terhadap standar kinerja. Strandar kinerja harus dijaga agar tujuan yang diharapkan dapat dicapai. Proses manajemen kinerja Torrington dan Hall dapat dilihat pada gambar berikut ini.

Proses ini meliputi kegiatan membangun harapan yang jelas serta pemahaman mengenai pekerjaan yang akan dilakukan. Ini merupakan sebuah sistem. ...".

Berdasarkan uraian di atas, Terdapat lima aspek esensial core performance, yaitu (1) Kurikulum; (2) Kompetensi guru; (3) Tampilan kinerja; (4) Perangkat pembelajaran. Terdapat tujuh aspek esensial supporting element, yaitu (1) Assignment guru (utilization); (2) Motivasi sebagai guru; (3) Kondisi kerja; (4) Supervisi guru; (5) Pengembangan profesi berkelanjutan; (6) Evaluasi kinerja; dan (7) Cost (pembiayaan). Terdapat faktor leadership (school principalship) yang berperan mengkoordinasikan, melakukan sinkronisasi, menjadi pengendali manajemen kinerja, dan melakukan kesamaan visi. Peran leadership ini dibebankan kepada kepala sekolah sebagai pimpinan satuan pendidikan.

\section{Kerangka Pemikiran Penelitian}

Mengacu pada manajemen kinerja model Torrington dan Hall), penulis mencoba menurunkan model tersebut sehingga nampak adanya kebaruan (noverlty) dari gagasan penelitian yang penulis lakukan. Gagasan tersebut berupa kerangka pemikiran yang mempertimbangkan unsur utama (core performance), unsur pendukung (supporting 
elements), dan fungsi kepemimpinan kepala sekolah untuk mewujudkan efektivitas keterlaksanaan proses dan keterlaksanaan hasil pembelajaran yang dilakukan guru

Dari sisi rasionalitas, ada fase krusial yang menobatkan guru sebagai tenaga profesional, penulis menyebutnya pada fase pemantapan kinerja atau kemapanan menjadi guru (manajemen kinerja). Agar lebih bermakna, pada tahapan ini harus digali sejumlah aspek esensial yang tidak terpisahkan dan mempengaruhi efektivitas kinerja. Penulis mendapatinya sebanyak dua belas aspek esensial

Diasumsikan dan diyakini bahwa aspek esensial tersebut dapat mempengaruhi keterlaksanaan proses yang efektif serta ketercapaian hasil yang efisien. Sebab, dari sisi konsep manajemen kinerja model Torrington dan Hall, empat aspek yang dikemukakan, yaitu determining performance expectations (menentukan tujuan-tujuan kinerja), supporting performance (menentukan dukungan kinerja), reviewing and appraising performance (mereview dan menilai), dan reviewing performance standards (mengelola standar kinerja) terwakili oleh dua belas aspek yang penulis analisis.

Bila proses dan hasilnya efektif dan efisien, maka diyakini bahwa outputnya berupa guru yang profesional akan terbentuk. Dampak dari itu semua diharapkan tercapainya hasil belajar siswa yang memuaskan. Inilah yang menjadi indikator efektivitas gagasan penelitian yang penulis kembangkan.

Agar gagasan penelitian ini dapat dilaksanakan, sebagai syaratnya penulis mengutip pendapat Wiener, Ross dan Jacobs, Ariel (2011) bahwa harus terjadi pembagian kewenangan dan tanggung jawab mulai dari level kelas, sekolah, hingga ke tingkat kabupaten/ kota. Jika demikian, mulai rasional, asumsi, indikator efektivitas, dan syarat pelaksanaan bahwa gagasan penelitian ini bisa diterapkan, maka visualisasi kerangka pemikiran penelitian ini tergambar sebagaimana skema berikut.

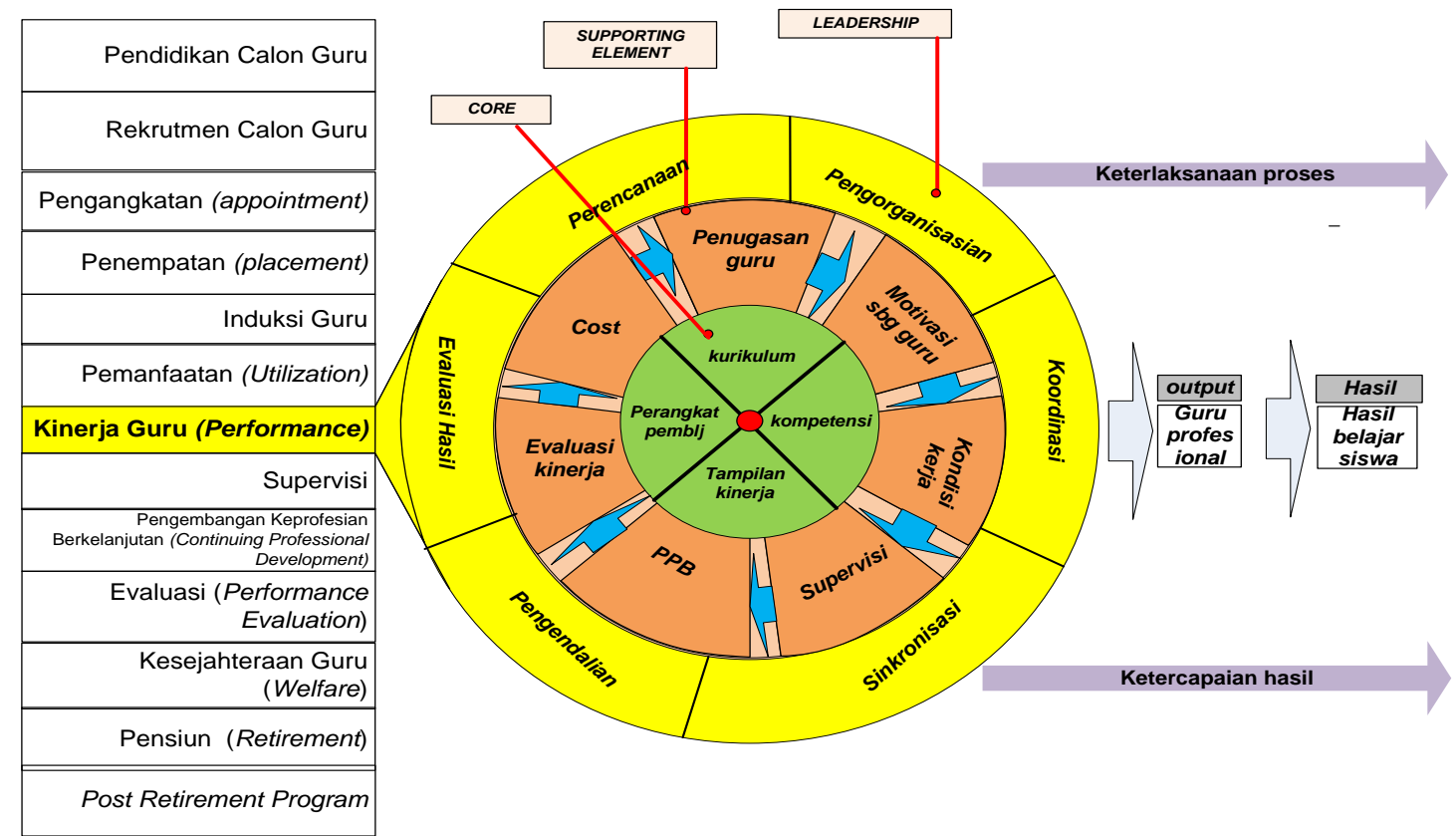

Gambar 2

Kerangka pemikiran penelitian

\section{METODE PENELITIAN}

Penelitian ini menerapkan pendekatan kualitatif dengan jenis studi kasus, yaitu mencoba mempelajari suatu fenomena dalam konteks yang nyata. Penelitian ini dilakukan di wilayah Kabupaten Sukabumi, yang mencakup 47 kecamatan. Selanjutnya, kecamatan tersebut 
tersebar dalam kluster-kluster terpencil dan tidak terpencil. Mengingat pengkajian tentang manajemen kinerja tersebut perlu difokuskan pada level kajian operasional (praktis), maka peneliti lakukan pengkajian pada level mikro atau persekolahan. Guru dan kepala sekolah menjadi sumber data utama, sedangkan sekolah dijadikan sebagai obyek lembaga/ organisasi kajian pada penelitian ini.

Pengelolaan guru SD yang dilakukan oleh Dinas Pendidikan Kabupaten Sukabumi saat ini berupa kategorisasi keterpencilan (Ring 1 dan Ring 2), kondisi SD berdasarkan kluster (kategorisasi keterpencilan) dapat dilustrasikan melalui gambar berikut ini.

\begin{tabular}{|l|l|}
\hline Kluster 1, kondisi & $\begin{array}{l}\text { Kluster 2, kondisi } \\
\text { SD yang } \\
\text { SD yang } \\
\text { dikategorikan } \\
\text { terpencil sesuai SE } \\
\text { Dirjen Dikdas No. : } \\
\text { 58/B5.1/LL/2014, } \\
\text { 268/C5.1/LL/2014, } \\
\text { terpencil, yaitu } \\
\text { tersebar di sekitar } \\
\text { perbatasan dengan } \\
\text { tgl, 15-1-2014, SD } \\
\text { Kota Sukabumi, } \\
\text { Kab. Bogor, Kab. } \\
\text { Cianjur, serta di } \\
\text { sepanjang jalan } \\
\text { nas. yg melintas di } \\
\text { Kab. Sukabumi }\end{array}$ \\
\hline
\end{tabular}

Gambar 3

Perbedaan Kluster 1 dan Kluster 2 tentang ketersebaran Sekolah Dasar

Populasi penelitian ini adalah semua guru Sekolah Dasar yang telah ditetapkan dengan aturan sebagai guru kelas yang mengajar di Sekolah Dasar dengan kriteria mengajar sebagai guru kelas rendah, yaitu kelas 1, 2, dan 3 serta mengajar sebagai guru kelas tinggi, yaitu kelas 4, 5, dan 6 .

Peneliti menempuh studi kasus pada guru Sekolah Dasar (SD) di wilayah Kabupaten Sukabumi. Hingga penelitian ini dibuat tercatat guru SD sebanyak 11.579 orang (Disdik Kab. Sukabumi, 2014) yang tersebar di 1.195 Sekolah Dasar baik sekolah negeri maupun swasta. Mengingat secara nasional hingga tahun 2014 Kabupaten Sukabumi termasuk kabupaten daerah terpencil, maka ada kelompok guru yang mengajar di sekolah yang dikategorikan daerah khusus (terpencil) sebanyak 1.691 guru yang tersebar mengajar di 210 SD khusus, sisanya tersebar di sekolah-sekolah di luar kategori khusus.

Atas dasar karakteristik Kabupaten Sukabumi, maka sampel penelitian ditempuh melalui prosedur purposive sampling yang didasarkan pada cluster system yaitu dilakukan pada sejumlah guru yang mewakili kategori terpencil dan tidak terpencil. Khusus yang dikategorikan bukan daerah terpencil, diambil pula sejumlah guru di sepanjang jalur jalan utama.

Agar penelitian ini terarah sesuai dengan tujuan yang diharapkan, peneliti menyusun pedoman wawancara, pedoman observasi, dan studi dokumentasi sebagi instrumen penelitian. Proses pengumpulan data diawali dengan mengobservasi responden, kemudian melakukan wawancara, disertai dengan meneliti setiap dokumen yang relevan. Pengolahan data dilakukan dengan membuat kategorisasi, sinkronisasi, dan integrasi data dengan cara memilah data dan mengemas informasi berdasarkan pertanyaan penelitian. Mengacu pada kerangka analisis data kualitatif yang dikembangkan oleh Miles, M. B. and Huberman, A. M. (1994), analisis data dilakukan secara induktif, yaitu dari data rinci yang spesifik kepada kategori dan sub kategori yang bersifat umum, yang dibangun berdasarkan pertanyaan penelitian. 
Tabel 1

Desain Penelusuran Dan Pengumpulan Data

Berdasarkan Pertanyaan Penelitian Dan Jenis Instrumen Penelitian

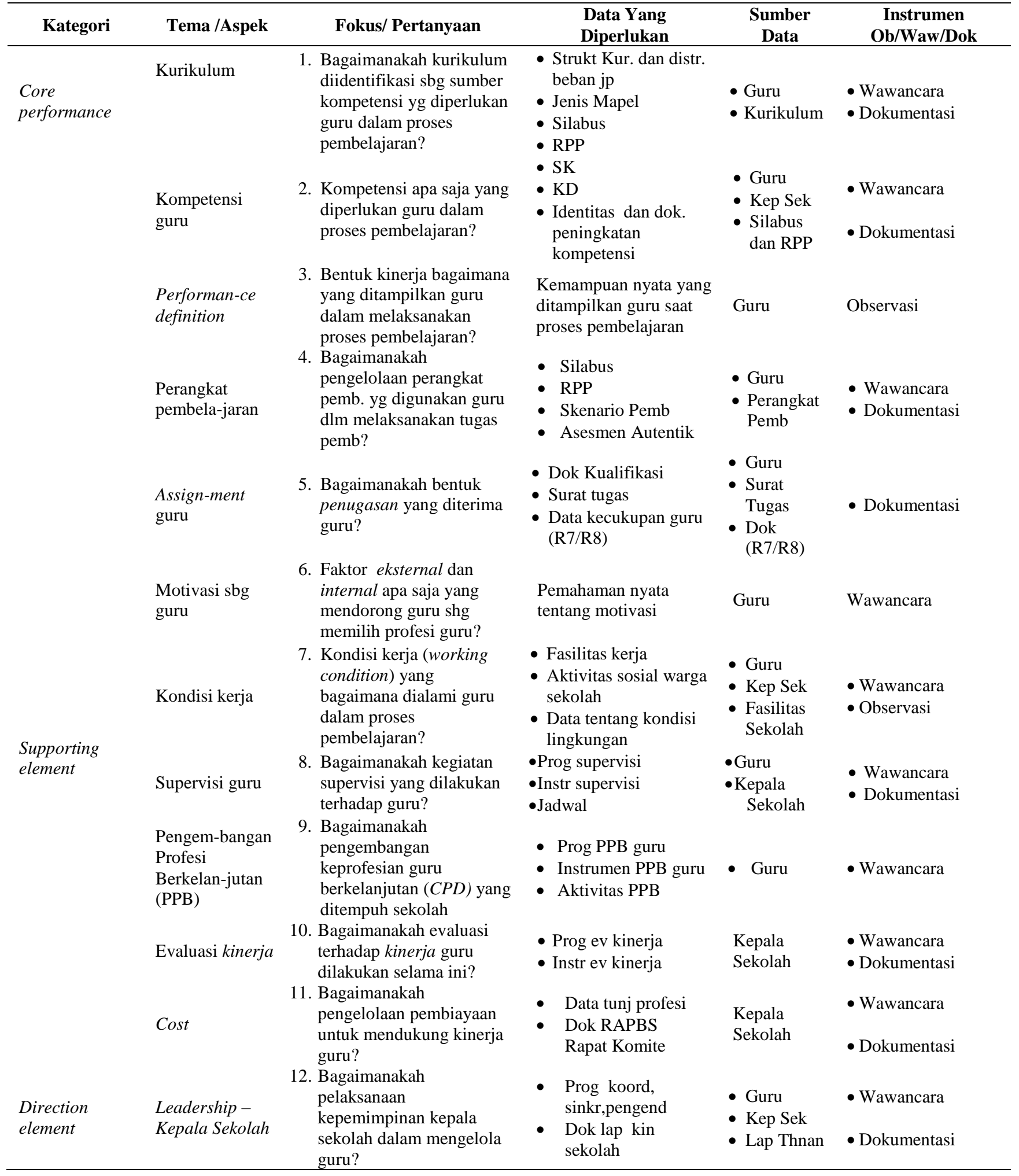




\section{Kurikulum sebagai Sumber Kompetensi Guru}

Kurikulum 2006 merupakan sumber kompetensi. Sebab, pada bagian khusus dari kurikulum ini diuraikan tentang Standar Kompetensi dan Kompetensi Dasar dari setiap mata pelajaran di SD sebagai bahan bagi guru untuk melakukan pembelajaran.

Umumnya guru membaca dan mempelajari dokumen kurikulum tidaklah tuntas. Lebih suka mendengar dari rekan atau mengikuti kegiatan penataran dan pertemuan dalam komunitasnya. Lebih bersifat menunggu perintah dari kepala sekolah, atau baru bergerak mempelajarinya setelah pengawas melakukan visitasi ke sekolahnya. Tidak jarang didapati guru yang tidak lengkap memiliki dokumen kurikulum yang dibutuhkan.

Guru telah berupaya menjadikan kurikulum sebagai sumber kompetensi melalui kegiatan: penelaahan terhadap kurikulum yang digunakan, kemudian dituangkan dalam analisis struktur dan muatan kurikulum, distribusi jam pelajaran per tatap muka, membuat kriteria ketuntasan belajar dan kenaikan kelas, menyusun kalender pendidikan, dan diakhiri dengan kegiatan sinkronisasi standar kompetensi dan kompetensi dasar dari setiap mata pelajaran

Menggali informasi tentang apa dan bagaimana kurikulum yang digunakan di sekolah seyogyanya menjadi kegiatan pertama guru ketika mengawali sebuah pembelajaran. Sebab, pada benak guru semestinya tertanam fungsi dan peran kurikulum dalam sebuah pembelajaran. Hal ini sebagaimana pernyataan Romine (dalam Hamalik, Oemar., 2010) "Curriculum is interpreted to mean all of the organized courses, activities, and experiences which pupil have under direction of the school, whether in the clasroom or not ...". Dengan demikian, bila guru hendak melakukan tugas pembelajaran, maka awal dari kegiatan pembelajaran yang dilakukan guru adalah membedah kurikulum yang diberlakukan untuk mendapatkan informasi standar kompetensi dan kompetensi dasar apa saja yang ingin dicapai pada setiap mata pelajaran di setiap tingkatan kelas.

\section{Capaian Kompetensi yang Diperlukan Guru dalam Proses Pembelajaran}

Para guru memaknai kompetensi sebagai kemampuan bersikap, berpikir, dan bertindak secara konsisten sebagai perwujudan dari pengetahuan, sikap, dan keterampilan yang dimiliki oleh peserta didik. Saat mereka harus menuangkan ke dalam bentuk tulisan perangkat pembelajaran, mereka melakukannya dengan runtut, yaitu dimulai dari menganalisis kurikulum terkait beban jam belajar anak untuk setiap mapelnya, hingga menyusun uraian kompetensi yang harus dimiliki siswa ketika usai pembelajarn. Caranya, dimulai dari menyusun silabus, hingga memetakan SK dan KD dalam satu perangkat pembelajaran yang disebut Rencana Pelaksanaan Pembelajaran.

Ketika berlanjut pada pertanyaan tentang kompetensi apa saja yang diperlukan guru dalam proses pembelajaran. Para guru hampir seragam dalam menjawab bahwa seorang guru dituntut memiliki kompetensi pedagogik, kompetensi profesional, kompetensi personal, dan kompetensi sosial.

Selain capaian kompetensi yang harus dimiliki guru, maka tidak kalah pentingnya adalah capaian kompetensi siswa sebagai ukuran hasil belajar. Kompetensi bagi siswa dicapai dengan cara guru merunut kompetensi mulai dari standar kompetensi, kompetensi dasar, dan indikator pembelajaran. Itu dituangkan dalam silabus dan RPP yang dibuat sendiri guru

Capaian kompetensi dapat dipandang sebagai tujuan pembelajaran yang dideskripsikan secara eksplisit, sehingga dijadikan standar dalam pencapaian tujuan kurikulum. Sesuai dengan pendapat Robert A. Roe (2001) bahwa terdapat beberapa aspek di dalam kompetensi sebagai tujuan, antara lain: Pengetahuan (knowlegde), Pemahaman (understanding), Kemahiran (skill), Nilai (value), Sikap (attitude), dan Minat (interest).

Mengutip gagasan David C. McClelland (dalam Vazirani, N. 2010), menurutnya bahwa kompetensi berkaitan dengan apa yang seseorang bisa lakukan, dan bukan hanya apa yang telah mereka ketahui. Implikasinya adalah kompetensi terkait dengan apa yang dilakukan harus memiliki konteks.

\section{Kinerja yang ditampilkan guru dalam melaksanakan proses pembelajaran \\ Kinerja guru yang dimaksud dalam} penelitian ini adalah unjuk kerja guru SD dalam mengelola kelas dan melakukan pembelajaran di hadapan siswanya melalui rangkaian kegiatan pendahuluan, kegiatan inti, dan kegiatan penutup.

Persoalan yang ditemukan saat guru melakukan kegiatan pendahuluan di antaranya pemilihan situasi, cerita, prilaku, atau, ketidaksiapan alat dan media peraga pembelajaran acapkali terjadi di kelas rendah maupun tinggi. 
Persoalan pun ditemukan ketika memasuki kegiatan inti. Upaya guru mengeksplorasi siswa tidak berjalan normal. Interaksi pembelajaran hanya berlangsung antara guru dan siswa. Tahap elaborasi cenderung seragam terjadi, yaitu guru meminta jawaban permasalahan kepada siswa, kemudian langsung membahas dan menjelaskan konsep dimaksud.

Sesuai dengan pendapat Mulyasa, E. (2005) bahwa kegiatan pembelajaran yang secara runtut haruslah mengikuti alur kegiatan pendahuluan, kegiatan inti, dan kegiatan penutup. Begitu pula menurut pernyataan Houston, W.R, Clift, R.T. Freiberg, HJ, WarnerA.R, (1988) bahwa secara umum tahapan pembelajaran menjadi tiga tahapan, yaitu kegiatan prapembelajaran atau kegiatan awal pembelajaran, kegiatan inti pembelajaran dan kegiatan akhir pembelajaran. Setiap tahapan tersebut ditempuh secara sistematis, efektif dan efisien.

Setelah melihat kelengkapan unsur dan efektivitas dalam setiap rangkaian kegiatan pembelajaran mulai dari pendahuluan, inti, hingga penutup, nampak bahwa guru dapat diklasifikasikan dalam kelompok kurang, kelompok biasa saja, dan kelompok yang bagus. Sebaran setiap klasifikasi tersebut terjadi pada guru di kelas rendah maupun di kelas tinggi.

\section{Pengelolaan perangkat pembelajaran}

Temuannya bahwa perangkat pembelajaran yang dikelola guru SD dalam melaksanakan pembelajaran meliputi: Silabus, RPP, Pemetaan Indikator Pembelajaran, dan Kisi-Kisi Penulisan Soal. Perangkat pembelajaran tersebut dibuat oleh guru atau sekelompok guru yang tergabung dalam gugus kerja guru. Belum semua guru menyusun dan mengelola perangkat pembelajaran ini sesuai dengan standar proses pembelajaran yang berlaku. Ditambah masih banyaknya ditemukan guru yang malas menyusun RPP secara lengkap. Diakui sebagian besar guru bahwa keberadaan perangkat pembelajaran tersebut sangat membantu guru ketika melakukan proses pembelajaran. Karena itu, guru yang memiliki dan mengelola dengan benar perangkat pembelajaran tersebut di atas cenderung efektif dalam melaksanakan proses pembelajaran

Menurut Hudoyo, H (1988) dan amanat Kemendikbud (dalam Depdiknas 2008) bahwa pengelolaan perangkat pembelajaran yang meliputi silabus, RPP, pemetaan indikator, serta kisi-kisi soal seharusnya didesain dan dilaksanakan dengan optimal. sesuai panduan penyusunan perangkat pembelajaran, yaitu Permendiknas RI No. 41 Tahun 2007 tentang Standar Proses.

\section{Bentuk penugasan yang diterima guru}

Dokumen yang terungkap dalam penelitian ini sebagai kelengkapan penugasan seseorang menjadi guru di antaranya: Surat keputusan penempatan dan penugasan menjadi guru, Profil data kecukupan guru (R7 dan R8), Dokumen kualifikasi pendidikan guru, Surat tugas mengajar, dan Jadwal pelajaran. Temuannya adalah sebagai berikut. (1) Jumlah guru SD masih kurang untuk bisa melayani pembelajaran sebagai guru kelas di seluruh SD. (2) Kualifikasi guru hampir seluruhnya menyandang kualifikasi S1. (3) Masih banyak guru yang tidak melengkapi tugas profesinya dengan Surat Tugas Mengajar. (4) Guru tidak tetap banyak diangkat secara mandiri oleh kepala sekolah guna menutupi layanan pembelajaran untuk setiap kelasnya. Padahal ini sangat riskan bila ditinjau dari segi aturan yang melarang Pejabat Pembina Kepegawaian di daerah untuk mengangkat guru tidak tetap sejak 1 Januari 2005.

Sejalan dengan penuturan Usman, M.U. (1995) dan UU No. 14/ 2005 tentang guru dan Dosen, sebagai bukti keabsahan seorang guru bertugas secara formal, maka kepadanya diberikan surat penugasan. Sesuai hal di atas, maka bentuk penugasan yang diterima guru selayaknya memperhatikan: kualifikasi akademik, latar belakang pendidikan tinggi; dan sertifikasi profesi. Linieritas ketiga hal tersebut dengan penugasan yang diterimanya setelah berada di lapangan, terutama di SD cenderung diabaikan. Harus ada keberanian setiap kepala sekolah untuk menerapkan permendagri no. 48 tahun 2005 bahwa pejabat pembina kepegawaian di tingkat pemerintah daerah tidak diperbolehkan lagi mengangkat guru honorer. Bila aturan ini dijalankan dengan semangat memperbaiki manajemen kinerja guru SD, diyakini mampu memperbaiki manajemen kinerja guru SD secara serempak

\section{Faktor-faktor internal dan eksternal yang memotivasi seseorang tetap bekerja sebagai guru}

Sebagian guru menjawab bahwa mereka menyukai menjadi guru karena mereka menyukai terjun ke dunia pendidikan. Hal ini lah yang mempertahankan seseorang untuk tetap nyaman bekerja sebagai guru. Sebagian guru lainnya menjawab bahwa banyak kesan yang menarik ketika mengajar anak-anak yang memiliki berbagai karakter dan penuh dengan canda tawa. Ketika berbaur dengan siswa dapat menghilangkan rasa kejenuhan dan stress. 
Sementara faktor eksternal, terutama iklim kerja yang tidak kondusif banyak mengganggu ketetapan hati seseorang untuk tidak melanjutkan profesinya menjadi guru.

Mengutip pendapat Abraham Maslow (dalam Indrawaty, 2006) tentang faktor eksternal dan internal dalam teori hierarki kebutuhan, maka seseorang yang berketetapan untuk mempertahankan profesinnya sebagai guru pun tidak lepas dari pengaruh fakor-faktor internal dan eksternal. Faktor-faktor seperti panggilan nurani, ingin senantiasa berbagi kebaikan, ingin menjadi inspirator yang berguna buat orang banyak, ikhlas berbagi pengetahuan dan senang berada di tengah anak-anak merupakan faktor internal yang kuat memaksa seseorang untuk tetap berprofesi sebagai guru.

Faktor-faktor seperti penghargaan keluarga dan masyarakat, tertarik karena perhatian pemerintah begitu berlebih terhadap guru, desakan untuk membutuhkan pekerjaan tetap, jaminan masa depan, atau terkesan dengan status dan citra guru merupakan contoh faktor eksternal yang melatarbelakangi seseorang untuk tetap bertahan berprofesi sebagai guru. Faktor eksternal tidak terlahir dari panggilan jiwa. Karena itu, mereka yang bertahan menjadi guru karena didominasi oleh faktor eksternal cenderung kurang bisa bertahan lama.

\section{Kondisi kerja guru}

Fasilitias langsung yang mendukung guru melaksanakan tugasnya seperti ruang guru dan sarana pendukung yang berupa meja-kursi guru, buku referensi, alat tulis menulis, perangkat TIK, banyak yang tidak layak. Lingkungan kerja termasuk semua sarana dan prasarana yang tersedia di sekolah sebagai penunjang tidak langsung pada pelaksanaan tugas guru seperti kondisi kelayakan bangunan, kondisi ruang kelas, perpustakaan, jamban dan sanitasi, sarana ibadah, keselamatan, kesehatan, dan pencemaran, serta kemudahan akses belum sepenuhnya tersedia dan terperhatikan dengan baik. Human relation yang berupa hubungan kerja antar guru, hubungan guru dengan kepala sekolah, dan hubungan guru dengan siswa, serta hubungan guru dengan orang tua siswa dan masyarakat sekitar sudah terbangun dengan baik.

Kondisi kerja yang meliputi fasilitas, lingkungan kerja, dan human relation memberi banyak peranan terhadap kelancaran guru menjalankan profesinya. Sebagaimana Cohen, J., McCabe, Elizabeth M., Michelli, Nicholas M., Pickeral, T (2009) menyatakan "school climate as the quality and character of school life based on patterns of students', parents' and school personnel's experience of school life and reflects norms, goals, values, interpersonal relationships, teaching and learning practices, and organizational structures".

Karena itu, kelangkapan sarana dan prasarana sekolah hendaknya menjadi perhatian khusus kepala sekolah bila ingin memanfaatkan kondisi kerja terhadap gairah bekerja para guru. Guru yang terfasilitasi sarana prasarananya cenderung semangat melakukan tugas profesinya.

\section{Supervisi guru}

Hampir semua sekolah telah menyusun program dan kegiatan supervisi. Program, kegiatan, bahkan anggaran tentang supervisi telah dituangkan dalam Program Kerja Kepala Sekolah. Akan tetapi, pelaksanaan supervisi dilakukan haruslah berberntuk penilaian kelas, sehingga yang terjadi adalah kepala sekolah atau pengawas masuk ke dalam kelas sambil membawa instrumen untuk diisi dan diberi catatan, tidak ada diskusi, tidak ada saran, apalagi contoh. Selesailah kegiatan supervisi tersebut. Itulah yang terjadi selama ini. Sulit ditemukan dokumen pelengkap dan bukti bahwa kegiatan supervisi telah dilaksanakan sekolah, bahkan pada guru sekalipun. Terkecuali dokumen kepala sekolah tentang program kerja kepala sekolah yang didalamnya ada uraian kegiatan supervisi berikut dana yang harus dikeluarkan. Tidak ada dokumen jadwal rutin supervisi dari pengawas sebagai pembina dan motivator peningkatan kinerja guru. Yang ada hanyalah jadwal tentatif kunjungan pengawas datang ke sekolah

Supervisi haruslah dipandang sebagai proses pembinaan, perbaikan, dan pengembangan pengelolaan pembelajaran. Menurut Alfonso, Neagley dan Evans, serta Marks Stroops (dalam Satori, Djam'an. 2004), melukiskan hubungan supervisi, proses mengajar belajar dan hasil belajar seperti dapat dilihat pada model berikut:

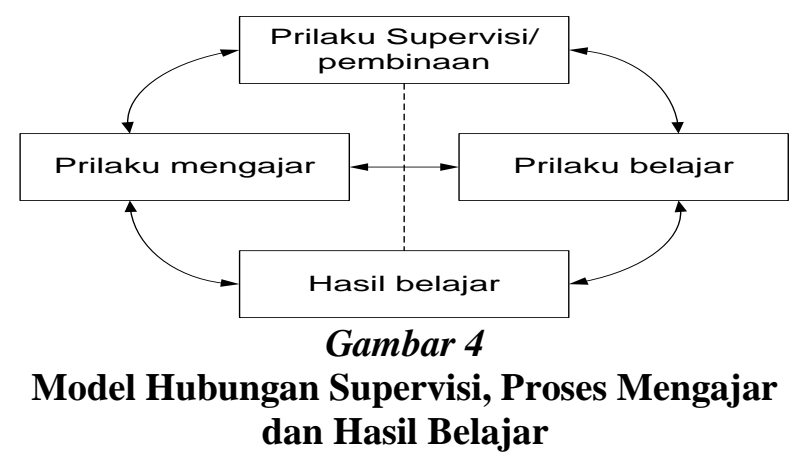

Karena itu, kegiatannya bisa berupa Kunjungan kelas secara berencana; Pertemuan pribadi antara supervisor dengan guru; Rapat 
antara supervisor dengan para guru; Kunjungan antar kelas atau antar sekolah; Pertemuanpertemuan di kelompok kerja guru.

\section{Pengembangan profesi guru berkelanjutan (Continuous Professional Development of Teacher)}

Kegiatan pengembangan profesi berkelanjutan bagi guru terkait pengembangan sebagai pribadinya (personal) dan pengembangan sebagai profesinya. Pengembangan profesi guru menjadi lancar diutarakan guru ketika ditanyakan apakah mereka itu melakukan pengembangan profesi? Tetapi akan tersendat ketika kepada mereka dimintai sejumlah bukti fisik apa yang telah dilakukannya. Inilah fenomena guru Sekolah Dasar, meskipun dokumen program dan kegiatan telah dibuat, tetapi tidak banyak yang bisa menunjukkan bukti kegiatan dengan lengkap

Secara detail konsep pengembangan profesi guru berkelanjutan yang saat ini diusung Kemendikbud dituangkan dalam Pedoman CPD berdasarkan Permenegpan RB No. 16/ 2009 tentang Jabatan Fungsional Guru dan Angka Kreditnya. Hal ini sesuai dengan isi dari laporan The International Commission on Education for Twenty-first Century (Delors, J. 1996) yang menegaskan bahwa dalam perbaikan kualitas pendidikan hal yang paling penting untuk diutamakan adalah perbaikan dalam perekrutan atau pengangkatan guru, sistem pelatihan (inservice training system) bagi guru, status sosial guru, dan kondisi atau kinerja guru.

Pengembangan profesi berkelanjutan adalah pengembangan kompetensi guru yang dilaksanakan sesuai dengan kebutuhan, secara bertahap, dan berkelanjutan untuk meningkatkan profesionalisme guru. Karena itu, pengembangan profesi guru setidaknya harus memuat tiga hal pokok, yaitu tentang unsur, mekanisme, dan bukti fisik

\section{Evaluasi kinerja guru}

Penilaian kinerja guru difokuskan pada dimensi utama guru, yaitu perencanaan pembelajaran, pelaksanaan pembelajaran yang aktif dan efektif, serta penilaian pembelajaran. Cara sekolah melakukan penilaian kinerja guru selama ini dapat dibedakan berdasarkan sudah atau belumnya kepala sekolah dan guru mendapat pembimbingan dan pelatihan penilaian kinerja guru. Dari sisi waktu, terjadwal setahun dua kali. Penilainya adalah kepala sekolah, guru sejawat senior, atau pengawas sekolah yang datang sewaktu-waktu. Mekanismenya terbangun dari kesepakatan kepala sekolah dengan guru berdasarkan jadwal yang telah disusun mereka, sehingga persiapannya lebih terencana. Fokusnya pada kelengkapan administrasi pembelajaran (silabus, RPP, perangkat evaluasi), visitasi di ruang kelas untuk menilai kemampuan pengelolaan kelas, dan ada sebagian kepala sekolah yang juga menilai kinerja guru terkait kedisiplinan aparatur/ kepegawaiannya. Karena cara mengevaluasinya seperti itu, maka tidak banyak kepala sekolah yang bisa memperlihatkan portofolio kegiatan evaluasi kinerja.

Evaluasi kinerja guru semestinya sesuai dengan pernyataan Rothwell, W.J., Hohne, C.K., dan King, S.B. (2007) bahwa penilaian kinerja merupakan proses membandingkan hasil kerja seseorang dengan standar prestasi kerja yang telah ditetapkan oleh organisasi. Sehingga dengan penilaian kinerja ini akan dapat diketahui seberapa baik seseorang melakukan pekerjaan yang diberikan/ ditugaskan.

Sistem penilaian kinerja guru yang saat ini diperlukan adalah sebuah sistem penilaian kinerja berbasis bukti (evidence-based appraisal) yang didesain untuk mengevaluasi tingkatan kinerja guru secara individu dalam melaksanakan tugas utamanya sebagai guru profesional. Penilaian kinerja guru harus memiliki dua fungsi, yaitu kesatu untuk menilai unjuk kerja (kinerja) dan kedua untuk menghitung angka kredit yang diperoleh guru atas kinerjanya..

\section{Pengelolaan pembiayaan untuk mendukung peningkatan kinerja guru}

Kepala sekolah telah membuat dan menyusun program dan kegiatan peningkatan kinerja dan profesional guru berikut penganggarannya. Kepala sekolah tidak dapat memperlihatkan dokumen tentang: Data penerima tunjangan profesi dan Uraian penggunaan sebagian tunjangan profesi guru untuk peningkatan kierja profesional guru. Hal ini terjadi karena tidak ada perintah dan aturan khusus yang mengharuskan seorang guru melaporkan berapa persen dari tunjangan profesi yang diterimanya untuk kepentingan pengembangan profesinya.

Berdasarkan dokumen Rencana Kegiatan dan Anggaran Sekolah (RKAS) bahwa Sekolah Dasar hanya mendapatkan sumber penerimaan dari Bantuan Operasional Sekolah (BOS), setelah ada kebijakan sekolah gratis. BOS dimaksud bersumber dari BOS Pusat, BOS Provinsi, dan BOS Kabupaten.

Persoalan paling kentara terkait pengelolaan keuangan di Sekolah Dasar adalah keterbatasan tenaga profesional yang khusus menangani pengelolaan dana-dana yang ada di sekolah. 
Sekolah Dasar menggunakan seorang guru kelas untuk mengelola pembiayaan sekolah, termasuk pembiayaan yang mendukung kinerja guru. Hal ini menjadi kendala tersendiri ketika tidak setiap guru mau dan mampu melakukan pekerjaan itu. Apalagi guru tersebut juga terbebani dengan kewajiban mengajar. Hingga kini, persoalan tersebut belum terpecahkan.

Hasil temuan Becker (dalam

Psacharopoulos, G. dan Patrinos, 2004), terbukti bahwa negara-negara yang mengalami pertumbuhan pendapatan secara persisten juga memiliki pengeluaran yang besar di bidang pendidikan dan pelatihan untuk angkatan kerja mereka. Ini menunjukkan bahwa betapa dibutuhkannya pengelolaan pembiayaan untuk mendukung kinerja guru.

Dalam upaya mendukung kinerja guru, peran kepala sekolah sebagai otorisator dan ordonator dapat menunangkan ide peningkatan mutu guru ke dalam program dan kegiatan sekolah yang dimuat dalam RKAS. Guru dapat menggunakan sumber pribadi seperti tunjangan profesi yang diterimanya guna peningkatan kapasitasnya secara mandiri. Kepala Sekolah dan guru sama-sama memahami dan berupaya mencari alternatif sumber dana lain yang disahkan tapi tidak mengikat guna mendorong upaya peningkatan kapasitas sumber daya sekolah, khususnya sumber daya guru.

\section{Fungsi kepemimpinan Kepala Sekolah dalam mengelola guru}

Persoalan yang mencuat terjadi manakala kepala sekolah belum lama diangkat menduduki jabatannya. Pengenalan dan adaptasi yang lama dari seorang kepala sekolah yang baru, cukup mengganggu proses koordinasi ini. Ada pula kepala sekolah yang mendapati persoalan mengkoordinasikan peran-peran gurudi sekolahnya. Kepala Sekolah mengalami persoalan terkait mengorganisasikan dan koordinasi, yaitu memadukan dan menyederhanakan tugas guruguru yang keadaannya saling bergantungan. Misalnya, ketika pihak dinas dan instansi di kabupaten atau provinsi bahkan pusat mengharuskan partisipasi aktif guru mengikuti rangkaian kegiatan kinerja dari instansi berbeda, kepala sekolah dituntut pandai melakukan sinkronisasi kegiatan yang akan diikuti guru sehingga setiap guru bisa mendapatkan kesempatan memiliki pengetahuan yang seragam tetapi ditempuh dengan cara berbagi kegiatan. Temuan terkait Controlling (pengendalian). Misalnya, peluang dan kesempatan guru memberikan saran dan pendapat secara berkala dalam saluran terbuka dan etis, sehingga terjadi adanya rekan guru yang dipanggil pengawas pembinanya akibat terlalu nyaring menyuarakan saran dan pendapat yang tidak disetujui kepala sekolahnya.

Kepemimpinan kepala sekolah adalah sekaligus sebagai manajer di sekolah tersebut dikarenakan seorang pemimpin juga melaksanakan fungsi manajemen yang bertugas merencanakan, mengorganisasikan, mengontrol, dan memimpin sebagaimana yang dikemukakan oleh Larry Bossidy (dalam Dubrin, Andrew J., 2006). Dari sudut kebijakan dan regulasi yang ada, sebagaimana tertuang dalam Permendiknas No. 13/ 2007 tentang standar Kepala Sekolah/ madrasah dan Permendiknas No. 28/ 2010 tentang Penugasan Guru sebagai Kepala Sekolah/Madrasah bahwa Kepala Sekolah harus memenuhi kualifikasi khusus dan kualifikasi umum serta memiliki kompetensi kepribadian, kompetensi manajerial, kompetensi kewirausahaan, kompetensi supervisi, dan kompetensi sosial.

Persoalan kemampuan memimpin dalam bentuk koordinasi, sinkronisasi, dan pengendalian semestinya sudah terjawab sebelum Kepala Sekolah itu diangkat, ditetapkan, dan ditempatkan, serta ditugaskan menjadi Sekolah. Karena itu, terobosan dilakukan dengan melakukan berbagai inovasi dalam bentuk power strategies maupun fasilitative strategies. Adanya kebijakan yang saat ini dilakukan melalui satu komando LPPKS (Lembaga Pengembangan dan Pemberdayaan Kepala Sekolah) yang menjamin kapabilitas calon Kepala Sekolah dengan meyakinkan pengguna melalui penerbitan NUKS (Nomor Unik Kepala Sekolah) sebagai penanda bahwa yang bersangkutan layak ditempatkan dan diberi kepercayaan memimpin sekolah.

\section{Model Hipotetis tentang Manajemen Kinerja Guru SD}

Bagian ini diajukan sebagai konsekuensi logis kajian keterlaksanaan manajemen kinerja guru SD yang mempertimbangkan: (1) permasalahan yang ditemukan; (2) rasional; (3) landasan filosofis; (4) struktur dan mekanisme model; serta (5) implementasi model, maka peneliti mengajukan model hipotetis tentang manajemen kinerja guru Sekolah Dasar. Model ini merupakan alternatif keterlaksanaan proses dan ketercapaian tujuan manajemen kinerja guru sesuai harapan.

Berdasarkan permasalahan yang ditemukan dalam penelitian ini, maka dipandang perlu melakukan penguatan pada komponen-komponen manajemen kinerja guru yang penulis pilah 
berdasarkan unsur utama (core performance), komponen pendukung (supporting elements), dan faktor kepemimpinan kepala sekolah (school principalship as prime mover).

Model hipotetis manajemen kinerja guru SD yang diusulkan ini sejalan dengan kerangka berpikir manajemen kinerja yang dikemukakan oleh Torrington dan Hall (2008). Pemikiran Torrington dan Hall tentang empat aspek manajemen kinerja mengilhami keyakinan peneliti tentang dua belas aspek manajemen kinerja guru yang sifatnya mendukung bahkan melengkapi model Torrington dan Hall. Selain itu, model hipotetis tentang konseptual manajemen kinerja guru SD sebagaimana dijelaskan di atas, bisa diterapkan dan diyakini kebaruannya (novelty).

Bertolak dari pemikiran keterlaksanaan proses dan ketercapaian hasil pengelolaan kinerja guru SD yang dilandasi oleh filosofis sebagaimana dijelaskan di atas, maka penulis mengajukan paradigma sebagai hal esensial yang menjadi pegangan dan diyakini kebenarannya dalam implementasi model manajemen kinerja guru Sekolah Dasar, yaitu diasumsikan beberapa hal penting berikut ini.

a. manajemen kinerja guru SD ditopang aspek esensial dan tidak terpisahkan dari konteks life cycle dan mendukung terjadinya efektivitas kinerja guru, yaitu core performance, supporting elements, dan leadership as prime mover.

b. core performance memuat unsur: Kurikulum; Kompetensi guru; Tampilan Kinerja; dan Perangkat pembelajaran. Supporting elements memuat unsur: Penugasan guru; Motivasi sebagai guru; Kondisi kerja; Supervisi guru; Pengembangan profesi berkelanjutan; Evaluasi kinerja; dan Cost (pembiayaan), core performance dan supporting elements harus didukung oleh fungsi kepemimpinan sekolah

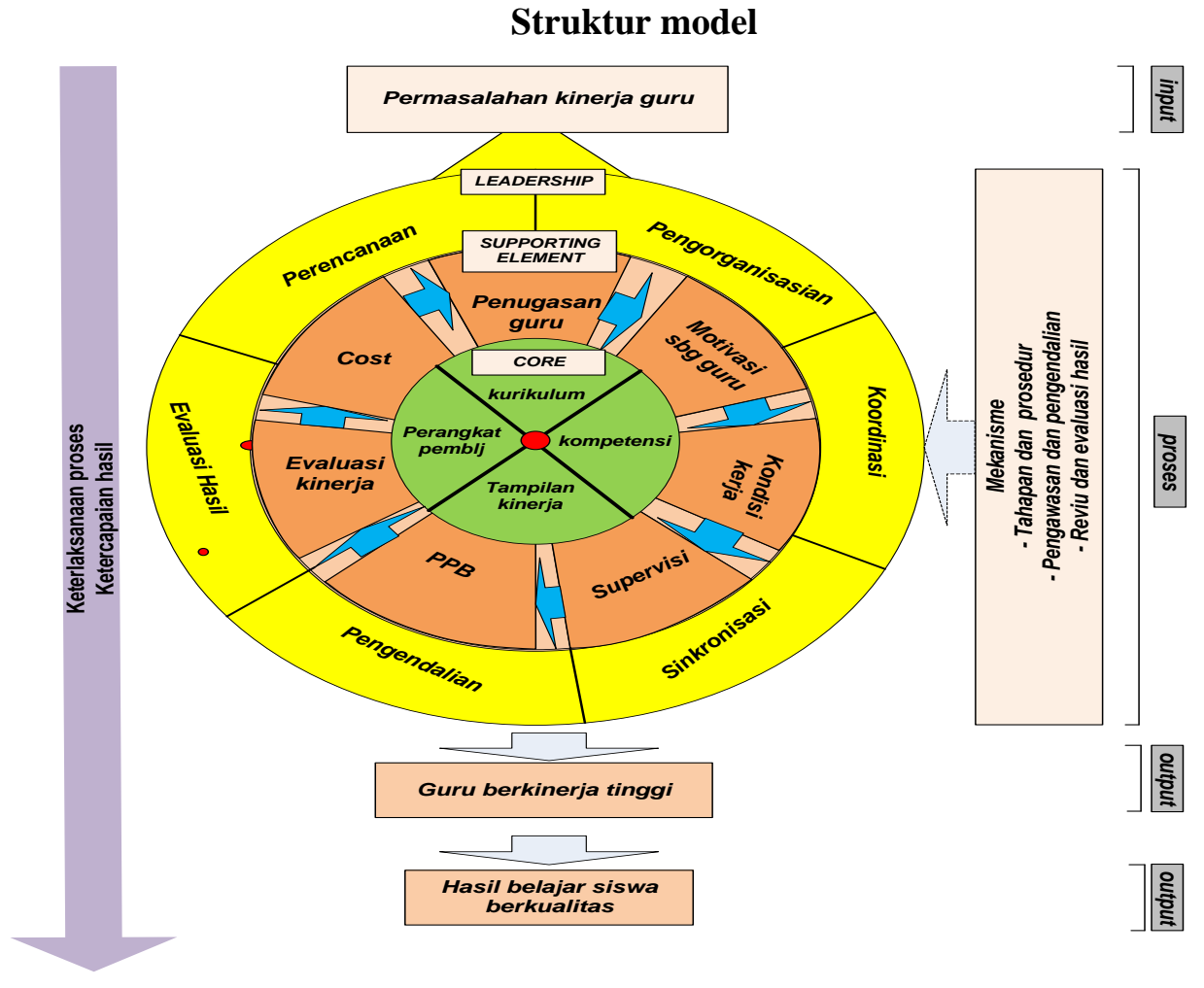

Gambar 5

Desain Struktur Model Manajemen Kinerja Guru SD

Seluruh rangkaian model hipotetis ini terbangun dalam konteks sistem manajemen. Layaknya sebuah sistem, maka yang menjadi inputnya adalah permasalahan kinerja guru, prosesnya adalah penerapan model yang melibatkan mekanisme model, sedangkan outputnya berupa guru berkinerja tinggi dan hasil belajar siswa yang berkualitas.

\section{Mekanisme model}

Mekanisme modelnya haruslah mencakup tahapan dan prosedur; pengawasan dan pengendalian; serta reviu dan evaluasi hasil. 
Tahapan yang dilakukan terkait dengan uruturutan kegiatan sebagai berikut:

Tahap 1 Menginventarisasi guru berdasarkan: tugas mengajar di kelas rendah atau kelas tinggi; kualifikasi pendidikan yang dimiliki; serta kluster sekolah. .

Tahap 2 Berdasarkan inventarisasi data tahap 1, maka disusunlah prioritas jenis-jenis kinerja yang menjadi fokus agar dikuasai guru.

Tahap 3 Meyusun rincian tugas siapa melakukan apa. Guru sebagai objek kegiatan, kepala sekolah sebagai prime mover, dan pengawas sekolah sebagai supervisor kegiatan.

Tahap 4 Melakukan distribusi pelaksanaan tugas guru, kepala sekolah, dan pengawas sekolah, misalnya dengan membuat matrik distribusi tugas.

Prosedur bagaimana model hipotetis ini dapat diterapkan berupa: sosialisasi, uji coba, penetapan waktu pelaksanaan, dan rangkaian action kegiatan di setiap sekolah. Sementara pengawasan dan pengendalian menjadi tanggung jawab pengelola pendidikan SD di setiap tingkatan atau level. Untuk karakteristik penelitian ini, penulis memandang perlu model hipotetis tersebut diterapkan pada setiap level kebijakan, yaitu mulai dari tingkatan kelas, dimana guru melakukan perlakuan belajar pada siswa, kemudian tingkat sekolah, hingga tingkat Dinas Pendidikan kabupaten/ kota.

Evaluasi dan reviu ditempuh pada setiap tingkatan kebijakan manajemen kinerja tersebut diberlakukan. Misalnya, pada level Disdik kabupaten/ kota, Kepala Dinas dapat mendelegasikan kewenangan manajemen kinerja kepada Kepala Bidang yang menangani kinerja dan kompetensi guru melalui evaluasi dan rekomendasi kegiatan pemberdayaan guru dan kepala sekolah pada setiap tahun anggaran.

\section{Implementasi model}

Agar gagasan penelitian ini dapat diimplementasikan, maka sebagai syaratnya penulis mencoba mengutip pendapat Wiener, Ross dan Jacobs, Ariel (2011) bahwa harus terjadi pembagian kewenangan dan tanggung jawab mulai dari level kelas, sekolah, hingga ke tingkat kabupaten/ kota.

Strategi implementasi diperlukan guna menjamin keberhasilan keterlaksanaan proses dan ketercapaian hasil. Pada awalnya, sekolah sebagai satuan kegiatan terkecil guru perlu melakukan kegiatan analisis lingkungan, kemudian melakukan sosialisasi program dan kegiatan. Berikutnya adalah uji coba penerapan model. Ini bisa ditempuh dengan syarat lokusnya benar-benar representatif. Hasil uji coba akan memperlihatkan kekuatan efektivitas dan efisiensi model. Selanjutnta menetapkan waktu pelaksanaan implementasi. Hal ini perlu ditempuh karena kegiatan akan berlangsung di sekolah, yaitu lembaga formal yang jelas kalender kegiatannya. Selain waktu, perlu pula penetapan tempat kegiatan implementasi model, terutama keterwakilan jumlah sekolah di setiap kluster. Hal ini dipertimbangkan mengingat karakteristik penelitian ini menjadi generalisasi hasil penelitian.

Dampak dari itu semua diharapkan tercapainya hasil belajar siswa yang memuaskan. Inilah indikator efektivitas keterlaksanaan proses dan keterlaksanaan hasil dari manajemen kinerja guru.

\section{SIMPULAN DAN REKOMENDASI}

\section{Simpulan Umum}

Manajemen kinerja guru SD yang mempertimbangkan unsur utama, unsur pendukung, dan fungsi kepemimpinan kepala sekolah diyakini dapat menjamin efektivitas keterlaksanaan proses dan keterlaksanaan hasil pembelajaran yang dilakukan guru. Model hipotetis manajemen kinerja guru SD disimpulkan sudah memadai dan mendukung serta melengkapi model pemikiran manajemen kinerja yang telah ada dengan suatu syarat harus terjadi manajemen pembagian kewenangan dan tanggung jawab mulai dari level kelas, sekolah, hingga ke pengelola setingkat Dinas Pendidikan.

\section{Simpulan Khusus}

Secara khusus, simpulan yang menjadi fokus kajian utama penelitian ini adalah sebagai berikut.

\section{Komponen kurikulum, kompetensi, tampilan kinerja, dan perangkat pembelajaran}

(1) Kurikulum 2006 merupakan sumber kompetensi bagi guru. Guru menuangkan hasil telaahan kurikulum ke dalam dokumen: analisis struktur dan muatan kurikulum, distribusi jam pelajaran per tatap muka, membuat kriteria ketuntasan belajar dan kenaikan kelas, menyusun kalender pendidikan, dan kegiatan sinkronisasi SKKD dari setiap mapel 
(2) Guru memaknai kompetensi guru meliputi kompetensi pedagogik, kepribadian, sosial, dan profesional. Sementara itu, kompetensi bagi siswa dicapai dengan cara guru merunut kompetensi mulai dari standar kompetensi, kompetensi dasar, dan indikator pembelajaran. Itu dituangkan dalam silabus dan RPP yang dibuat sendiri oleh guru.

(3) Unjuk kerja guru SD dalam mengelola kelas dan melakukan pembelajaran di hadapan siswanya ditempuh melalui rangkaian kegiatan pendahuluan, kegiatan inti, dan kegiatan penutup. Guru mengalami masalah dalam pengelolaan kelas, baik di kelas rendah maupun di kelas tinggi.

(4) Perangkat pembelajaran yang dikelola guru SD dalam melaksanakan pembelajaran meliputi: Silabus, RPP, Pemetaan Indikator Pembelajaran, dan Kisi-Kisi Penulisan Soal. Belum semua guru menyusun dan mengelola perangkat pembelajaran ini sesuai dengan standar proses pembelajaran yang berlaku.

2. Komponen penugasan guru, kondisi kerja, supervisi, pengembangan profesi, evaluasi kinerja, pembiayaan, faktor internal dan faktor eksternal.

(1) Penugasan guru disimpulkan: Jumlah guru SD masih kurang; Kualifikasi guru hampir seluruhnya menyandang kualifikasi S1; Masih banyak guru yang tidak melengkapi tugas profesinya dengan Surat Tugas Mengajar; Guru tidak tetap banyak diangkat secara mandiri oleh kepala sekolah guna menutupi layanan pembelajaran untuk setiap kelasnya..

(2)Faktor internal merupakan faktor yang kuat dan lahir dari dalam diri seseorang tanpa ada unsur paksaan dari siapa pun kerap kali menjadi penggerak utama bagi guru untuk tetap melakukan profesi sebagai guru. Sementara faktor eksternal, terutama iklim kerja yang tidak kondusif banyak mengganggu dan mempengaruhi seseorang untuk tidak melanjutkan profesinya menjadi guru.

(3) Working condition yang berupa fasilitas langsung yang mempengaruhi kerja guru memberi peranan kuat terhadap terciptanya kondisi kerja yang kondusif bagi seorang guru. Lingkungan kerja termasuk semua sarana dan prasarana yang tersedia di sekolah sebagai penunjang tidak langsung pada pelaksanaan tugas guru belum sepenuhnya tersedia dan terperhatikan dengan baik. Human relation mulai terbangun dengan baik.

(4) Supervisi yang terjadi saat ini sebatas pemahaman supervisi sebagai istilah lain dari penilaian. Kepala sekolah dan guru sedikit sekali yang bisa menunjukkan bahwa mereka telah menempuh kegiatan supervisi yang didukung oleh beberapa dokumen hasil dan rekomendasi dari kegiatan supervisi terhadapnya

(5) Kegiatan pengembangan profesi kerapkali diprogramkan tetapi seringkali tidak sesuai rencana. Pengembangan profesi berkelanjutan bagi guru mencakup kegiatan pengembangan diri, kegiatan publikasi ilmiah, dan kegiatan membuat karya inovatif

(6) Kepala Sekolah telah menyusun program evaluasi kinerja guru dalam bahasa yang beragam, seperti kegiatan: analisis kinerja guru, penilaian kapasitas guru, evaluasi dan rekomendasi kinerja guru, atau penilaian kinerja guru. Namun, tidak dilengkapi dokumen portofolionya

(7) Kepala sekolah telah menganggarkan kegiatan peningkatan kinerja dan profesional meskipun hanya bersumber dari Dana BOS. Guru dan kepala sekolah bersama-sama mencari sumber dana lainnya yang sah dan tidak mengikat guna peningkatan kapasitas dan kinerja guru

\section{Fungsi kepemimpinan kepala sekolah}

Fungsi kepala sekolah dalam menjalankan kepemimpinannya berperan sebagai perencana, organisator, koordinator, sebagai petugas yang melakukan sinkronisasi kerja, dan sebagai pengendali kebijakan kinerja guru. Pada peran perencanaan, pada umumnya kepala sekolah telah piawai melakukan fungsi manajemen ini. Kepala Sekolah mengalami persoalan terkait mengorganisasikan, mengkoordinasikan, menyinkronkan, dan mengendalikan kegiatan para guru dengan waktu yang bersamaan, sedangkan tempat dan judul kegiatan berbeda, padahal siswa harus terlayani dengan baik.

\section{Rekomendasi}

Berdasarkan simpulan sebagaimana tersebut di atas, maka peneliti merekomendasikan sebagai berikut.

\section{Rekomendasi penerapan model hipotetis}

Penerapan model yang digagas dalam penelitian ini, direkomendasikan mem-berikan penguatan pada unsur esensial manajemen 
kinerja guru yang termuat dalam komponen utama (4 unsur), komponen pendukung (7 unsur), dan fungsi kepemimpinan kepala sekolah diprediksi mampu menjamin terselenggaranya proses dan hasil berkualitas dalam penanganan pengelolaan kinerja guru SD

\section{Rekomendasi bagi Dinas Pendidikan}

a. Direkomendasikan kepada Dinas Pendidikan penting memiliki Struktur Organisasi Kerja Pemerintahan (SOTK) yang membidangi khusus tentang pembinaan guru dan tenaga kependidikan atau setidaknya gugus kerja setingkat eselon 3 yang di dalamnya memuat bagian atau seksi pembinaan guru dan tenaga kependidikan setiap jenjang dan jenis satuan pendidikan.

b. Untuk mengatasi kekurangan guru, direkomendasikan kepada Dinas Pendidikan agar mendesak Pemerintah Pusat membuat kebijakan baru tentang pemberian kuota kepada pemerintah daerah dalam mengangkat guru-PNS dan menyusun ulang regulasi pengangkatan guru yang tidak hanya berpaku pada ketersediaan guru PNS guna mengupayakan ketercukupan guru di Sekolah Dasar.

c. Dalam pemenuhan kualifikasi pendidikan guru minimal SI yang berkualitas direkomendasikan kepada Dinas Pendidikan agar mengeluarkan kebijakan tentang anjuran bagi guru menempuh pendidikan S1 maupun lanjutannya yang linier dan sesuai dengan tugas mengajar yang diampunya.

d. Terkait kelengkapan surat tugas mengajar direkomendasikan kepada Dinas Pendidikan agar senantiasa mengingatkan guru dan kepala sekolah untuk selalu melengkapi surat tugas mengajar sebelum seorang guru memulai tugas mengajarnya dan diup date ke dalam aplikasi yang tepat sesuai kebijakan yang sedang berjalan.

e. Dalam hal keberadaan guru tidak tetap hendaknya dipandang jangan menjadi kebijakan permanen. Karena itu, direkomendasikan pula kepada Dinas Pendidikan agar pro aktif membangun kebijakan lokal di tingkat sekolah terhadap kepala sekolah dalam membuat keputusan perlu tidaknya mempekerjakan guru honorer.

\section{DAFTAR PUSTAKA}

Bacal, Robert. (2001). Performance Management. (Terjemahan Surya Darma dan Yanuar Irawan). Jakarta : PT Gramedia Pustaka Utama

Barber, M dan Mourshed, M. 2007. How The World's Best-Performing School Systems ComeOut On Top. No city: McKinsey \& Company (tersedia: http://www.merriamwebster.com)

Cohen, J., McCabe, Elizabeth M., Michelli, Nicholas M., Pickeral, T (2009), School Climate: Research, Policy, Practice, and Teacher Education. Teachers College Record Volume 111, Number 1, January 2009

Cummings, T.G Worley, C. G. (2001). Organization Development and Change. $7^{\text {th }}$ Edition. Ohio: South Western College Publishing

Delors, J. (1996), The International Commission on Education for Twentyfirst Century Report. UNESCO.

Depdiknas. (2008). Panduan Pengembangan Bahan Ajar. Jakarta: Direktorat Tenaga Kependidikan-Dirjen Peningkatan Mutu Pendidikan dan Tenaga Kependidikan
Dubrin, Andrew J. (2006). Leadership and Change. (tersedia: http://www.learningace.com/doc)

Gaffar, Fakry (1989). Perencanaan Pendidikan Teori dan Metodologi. Jakarta: P2LPTK

Hamalik, Oemar (2010). Manajemen Pengembangan Kurikulum. Bandung: PT. Remaja Rosdakarya

Houston, W.R, Clift, R.T. Freiberg, HJ, WarnerA.R, (1988), Touch The future Teach,StPaul: West Publishing Co (tersedia: https://www. academia.edu)

Huberman, M. (2001). The Professional Life Cycle of Teachers. Teachers College Record, 91 (1), pp. 31-58

Hudoyo, H. (1988). Mengajar Belajar Matematika. Jakarta: Dirjen Dikti Depdiknas

Miles, M. B. and Huberman, A. M. (1994). Qualitative data analysis: An expanded sourcebook, $2^{\text {nd }} E d$. Thousand Oaks: Sage. (tersedia: http://www.esourceresearch.org/ eSourceBook/ Software and Qualitative Analysis

Mulyasa, E. (2005). Menjadi kepala sekolah profesional, dalam konteks menyukseskan $M B S$ dan $K B K$. Bandung: Remaja Rosdakarya 
Permendiknas No. 28/ 2010 tentang Penugasan Guru sebagai Kepala Sekolah/Madrasah.

Permendiknas No. 13/ 2007 tentang standar Kepala Sekolah/ madrasah

Permendiknas No. 28/ 2010 tentang Penugasan Guru sebagai Kepala Sekolah/Madrasah bahwa Kepala Sekolah

Permendiknas No. 38/ 2010 tentang Penyesuaian Jabatan Fungsional Guru.

Permendiknas No. 41/2007 tentang Standar Proses

Permenegpan RB No. 16/ 2009 tentang Jabatan Fungsional Guru dan Angka Kreditnya

Psacharopoulos, G. And H.A Patrinos (2004) Returns To Investment In Education: A Further Update, Jurnal 12(2): 111-134

Robert A. Roe (2001). Pengertian Kompetensi. [Online]. Tersedia: http://www.docstoc.com/ [19 April 2009]

Rothwell, W.J., Hohne, C.K., dan King, S.B. (2007) Human Performance Improvement. Boston: Elsevier

Satori, Djam'an. 2004. Paradigma Baru Supervisi Pendidikan untuk Peningkatan Mutu dalam Konteks Peranan Pengawas Sekolah dalam Otonomi Daerah. Makalah pada Seminar Peranan Pengawas dalam Otonomi Daerah
17 Maret 2004. Bandung : APSI Provinsi Jawa Barat.

Tilaar, H.A.R. (2002). Pendidikan untuk Masyarakat Indonesia Baru. Jakarta: Pt. Gramedia

Torrington, D., Hall, L., Taylor, S. (2008) Human Resource Management. Financial Times Prentice Hall (E Book)

Usman, M.U. (1995). Menjadi Guru Profesional. Bandung: PT Rosdakarya.

Undang-Undang Nomor 14/ 2005 tentang Guru dan Dosen

Vazirani, N. (2010). Competencies and Competency Model-A Brief overview of its Development and Application. SIES Journal of Management, April - August 2010, Vol.7(1): 121-131

White, Ron (2008). Teachers' Professional Life Cycles. The IH Journal of Education and Development, Issue 24

White, Ron. 2008)

Wiener, Ross dan Jacobs, Ariel (2011). Designing and Implementing Teacher Performance Management Systems: Pitfalls and Possibilities. Washington D.C.: Education \& Society Program. (tersedia: www.aspeninstitute.org/education). 